\section{EXCAVATIONS AT TRES ZAPOTES, MEXICO*}

$\mathbf{A}^{\mathrm{N}}$ account has now been issued of the first season's work of the joint expedition of the National Geographic Society and the Smithsonian Institution to Tres Zapotes. The site is a large one, and the remains consist of earth mounds with little or no masonry. The deposits are tentatively assigned to three periods, Middle Tres Zapotes $A$ and $B$ and Upper Tres Zapotes. This nomenclature depends on the existence of a Lower Tres Zapotes horizon, discovered during the work of the second season.

The Middle $A$ and $B$ deposits were not found in superposition, but there is little doubt about their relative age. On one site, Upper Tres Zapotes was found overlying Middle $A$, but separated from it by $6 \mathrm{ft}$. of sterile deposit.

Middle Tres $Z$ apotes $A$ is associated. with large numbers of hand-made, solid clay figurines of archaic type, and although there is always a possibility that they are a late survival in a marginal area, the balance of the evidence favours an early date. The Middle $B$ period contains uncremated burials in large ollas. It is marked by the first appearance of painted pottery, and there are contacts with many other cultures, conspicuous among which is the Maya Old Empire. The Upper period contains cremated burials in covered bowls, and the pottery is of great complexity. A curious feature of the site is the paucity of Aztec remains.

The work described was admittedly exploratory and many problems are left unsolved. Some of the results of the work of the second season were already available when it went to press, so it seems a pity that publication was not delayed until they could be incorporated and a fuller picture given. The illustrations are good and clear, but should as a matter of routine have been provided with a scale in every case. The same criticism applies in a greater degree to maps 2 and 3 , and to the section which is, rather curiously, designated "Map 6".

\section{G. H. S. Bushnell.}

* Smithsonian Institution: Bureau of American Ethnology. Bull. 139. An Introduction to the Ceramics of Tres Zapotes, Veracruz, Mexico. By C. W. Weiant. Pp. xiv $+144+78$ plates. (Washington: Government Printing Office, 1943.) 40 cents.

\section{FORTHCOMING EVENTS}

Tuesday, July 25

Queretr Microscopical Cuub (at the Royal Society, Burlington House, Piccadilly, London, W.1), at 7 p.m.- Exhibition of Specimens and Discussion.

\section{APPOINTMENTS VACANT}

AppLIOAmIONs are invited for the following appointments on or before the dates mentioned

LECTURER IN EXPERIMENTAI PHYSIOLOGY-The Registrar, The University, Sheffield (July 28).

LECTURER IN THE ELECTRICAL ENGINEERING DEPARTMENT-The Registrar, Technical College, Sunderland (July 29).

JOHN RANKIN CHAIR OF GEOGRAPHY-The Registrar, The University, Liverpool (July 31).

W. H. COLLINS PROFESSORSHIP OF HuMAN AND COMPARATIVE PATHoLogY-The Secretary, Royal College of Surgeons of England, Lincoln's Inn Fields, London, W.C.2 (July 31).

SENIOR LECTURESHIP IN THE DEPARTMENT OF METALLURGY of the University of the Witwatersrand-Dr. W. Cullen, 4 Broad Street Place, London, E.C.2 (July 31).

PRINCIPAL OF THE MID-ESSEX TECHNICAL COLLEGE AND ScHOOI Chief Education Officer, County Offices, Chelmsford (August 5).

Assistant LECTURER in METALLURGY-The Acting Registrar, The University, Leeds 2 (August 12).
Assistant PHYSICIST to the Sheffield Radium Centre-The Secretary, Sheffield Radium Centre, Royal Inflrmary, Sheffleld 6 (August 12). BIOLOGIST at the West Midland Forensic Science Laboratory at Birmingham-The Establishment Oflicer, Room 320, Home Office, Whitehall, London, S.W.1 (August 12).

LEOTURER IN PHILOSOPHY - The Very Rev. the Dean, Christ Church, Oxford (October 15).

Lecturer IN Physiologr-The Principal, Nonington College of Physical Education, Bromsgrove.

Assistant PHYsIcist (with experience of the Physics of Radiotherapy)-Mr. S. Clayton Fryers, General Inflrmary, Leeds 1.

Sorfntific Assistant (Science Degree) and TECHNICAI Assistant (Arts Degree)-Imperial Bureau of Animal Health, Veterinary Laboratory, Ministry of Agriculture, New Haw, Weybridge, Surrey.

\section{REPORTS and other PUBLICATIONS (not included in the monthly Books Supplement) Great Britain and Ireland} Department of Scientific and Industrial Research. Index to the
Literature of Food Investigation. Vol. 15, No. 1, June 1943. Compiled by Agnes Elisabeth Glennie, assisted by Janet Lang Hall Keuneman. Pp. iv +86 . (London: H.M. Stationery Office.) 4s. $6 d$. net. P. Iv +86 . (London: H.M. Stationery Office.) 4s. $6 d$. Fitzwilliam Museum, Cambridge. Annual Report for the Year ending 31 December 1943. Pp. 10. Friends of the Fitzwilliam Museum Thirty-fifth Annual Report for the Year 1943. Pp. 4. (Cambridge: Fitzwilliam Museum.) British Society of Animal Production. Report of Inaugural Meeting, British Society of Animal Production. Report of naugural Meeting, (Edinburgh: Secretary-Treasurer, British Society of Animal Production, c/o Imperial Bureau of Animal Breeding and Genetics.) 28 . National Physical Laboratory. The Natural Lighting of Houses
[266 and Flats with Graded Daylight Factor Tables. By T. Smith and Miss E. D. Brown. Pp. 22. (London: H.M. Stationery Office.) $4 d$. net.

Burton-on-Trent NaturaI History and Archæological Society. Local Records for 1943. Edited by H. J. Wain. Pp. 24. (Burton-on-Trent: The Museum.) 18.
[276 Medical Research Council. Emergency Report No. 5 of the Industrial Health Research Board : A Study of Variations in Output. By S. Wyatt, assisted by R. Marriott, W. M. Dawson, D. E. R. Hughes and F. G. L. Stock. Pp. iv +16. (London: H.M. Stationery Office.) 4d. net.
[276 Lister Institute of Preventive Medicine. Report of the Governing Body, 1944. Pp. 16. (London: Lister Institute.) [276 Nuffield College. Problems of Scientiflc and Industrial Research : a Statement. Pp. 64. (London: Oxford University Press.) A Racial Survey of the British People. Lecture delivered to the Free German Institute of Science and Learning, London, on March 11, 1944. By Dr. R. E. G. Armattoe. Pp. 8. (Londonderry: The Author, 7 Northland Road.) 18. $6 d$.

Combine Harvesting in the North, 1943. (N.I.A.E. Publication No. 502/44.) Pp. 20. (York: National Institute of Agricultural Engineering.) $6 d$. Slough: Imperial Chemical Industries, Itd.)

\section{Other Countries}

Bulletin of the American Museum of Natural History. Vol. 82, Art. 8: Geographic Variation in Rana pipiens Schreber of Eastern North America. By John Alexander Moore. Pp. 345-370+plates 61-66. (New York: American Museum of Natural History.) [306 Indian Forest Leaflet No. 57: Furnace Heated Veneer Drying Kiln suitable for the Seasoning of Veneers for the Manufacture of Plywood. By M. A. Rehman. Pp. ii +6. 6 annas; $7 d$. Indian Forest Leaflet No. 60: A Short Note on the Beedi Leaf Industry. By Jag. damba Prasad. Pp. iii $+12+2$ plates. 6 annas; $7 d$. Indian Forest Leaflet No. 61 : Kiln Drying Schedule for Seasoning of Veneers. By M. A. Rehman and S. M. Ishaq. Pp. ii +7.6 annas; $7 d$. Indian Forest Leaflet No. 64 : The Growing of Cryptostegia grandiflora as a War Time Emergency Plantation Crop. By A. L. Griffith. Pp. iii +10 4 annas; $5 d$. (Dehra Dun : Forest Research Institute.) [47 Indian Forest Bulletin No. 121: Tests on the Suitability of Indian Woods for the Manufacture of Textile and Jute Mill Accessories, Part 1: Substitutes for Persimmon and Cornel for Cotton Mill Shuttles. By M. A. Rehman and Chheda Lal. Pp. 9. 4 annas; 5d. Indian Forest Bulletin No. 122: Tests on the Suitability of Indian Woods Forest Bulletin No. Textile and Jute Mill Accessories, Part 2 Care and Seasoning of Wood for Bobbins, Picker Arms, and Jute Mil Rollers. By M. A. Rehman. Pp. 7. 4 annas ; 5d. (Dehra Dun: Forest Rollers. By M. A. Rehman. Pp. 7. 4 annas; 5d. (Dehra Dun: Forest Research Institute.)
Indian Central Cotton Committee: Technological Laboratory. Indian Central Cotton Committee: Technological Laboratory. Technological Bulletin, Series A, No. 57 : Technological Reports on Trade Varieties of Indian Cottons, 1943. By Dr. Nazir Ahmad. Pp.
ix +84.1 .8 rupees. Technological Bulletin, Series A, No. 58: Techix +84.1 .8 rupees. Technological Bulletin, Series A, No. 58: Technological Reports on Standard Indian Cottons, 1943 . By Dr. Nazir Ahmad. Pp. iv +103. 1.8 rupees. Technological Bulletin, Series A, No. 59: Spinning Tests on Mixtures of Staple Fibre with Indian Cottons. By Srinagabhusahana and Dr. Nazir Ahmad. Pp. 27. 12 annas. (Bombay: Indian Central Cotton Committee.) Indian Forest Records (New Series). Silviculture, Vol. 4A, No. 4 :
Yield and Stand Tables for Sal (Shorea robusta, Gaertn.f.) High Forest. Yield and Stand Tables for Sal (Shorea robusta, Gaertn.f.) High Forest. By A. L. Griffith and Bakhshi Sant Ram. Pp. ix $+171-287+4$ plates. (Delhi : Forest Research Institute.) 2.14 rupees; $48.4 d$.
US Strains of the European Corn Borer in the United States. By K. D. Arbuthnot. Pp. 20. (Washington, D.C.: Government Printing Office.) 10 cents. 